\title{
パラメトリック曲面で定義されたラチスシェルの部材長一様化と 剛性最大化を目的とした形状最適化 \\ SHAPE OPTIMIZATION OF LATTICED SHELL DEFINED BY PARAMETRIC SURFACE FOR UNIFORM MEMBER LENGTH AND MAXIMUM STIFFNESS
}

\author{
藤田 慎之輔*1, 大 崎 純*2
}

\author{
Shinnosuke FUJITA and Makoto OHSAKI
}

\begin{abstract}
A method is presented for shape optimization of latticed shells defined by parametric surfaces. The latticed shells with rectangular and triangular grids are optimized for maximum stiffness (minimum strain energy) and constructability (uniform member lengths). It is first shown that the latticed shells with completely uniform member length can be generated by solving an optimization problem with nodal coordinates as design variables. Next, the latticed shells are modeled using Bézier surfaces in order to reduce the number of design valiables while maintaining the complexity and smoothness of the shell surface. Although the shape of a parametric surface is usually optimized using the coordinates of control points as design variables, we use the parameter values at the nodes of the grids, in addition to the coordinates of control points, as design variables. The optimization results using different design variables are compared in the numerical examples.
\end{abstract}

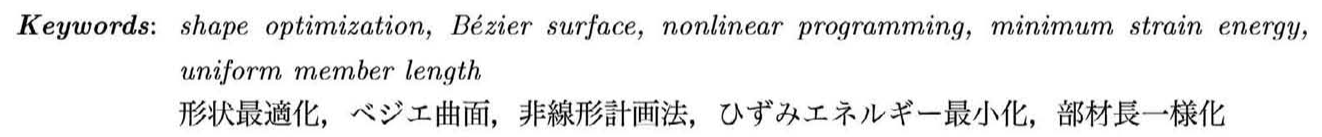

1 序

トラスの形状最適化については, 1970 年代から多くの研究が存在 する。初期の段階では, 主に平面トラスの節点座標を独立な連続変 数として, 数理計画法を用いて最適化している1-3)。

ラチスシェルの形状最適化については, 1990 年代になって, 幾何 学的非線形性を考慮した研究が発表されている4)。しかし, 多くの節 点をもつ曲面状トラスあるいは骨組では, すべての節点の 3 方向の 座標を設計変数とした場合, 最適化のために多くの計算量を必要と し, 滑らかでない曲面が生成される場合も多い。また, 力学的特性 のみを考慮すると, 部材長は極めて不均等になり, 部材の交差や重 複も発生することが考えられる。したがつて, 既往の研究の多くで は, 節点の鉛直方向座標のみを設計変数としている。

すべての節点の座標を設計変数として曲面を最適化し, 非現実的 な形状が得られることを避けるためには, 部材長に関する制約を与 えるのが有効である5)。ラチスシェルを設計する際には, 弾性剛性, 座屈荷重などの力学的性能を最適化することに加えて, 鉄骨量や接合 部コストなどといった経済性を考慮しなければならない。また，シエ
ル構造は力学合理性と建築形態に強い相関を有し，しばしば構造が そのまま意匠となって表れるため, 曲面の滑らかさや, 網目の均一 性といった意匠的側面も同時に考慮すべき重要な要素である。した がって, 最適化問題は, 非力学的性能を含めた複数の目標を考慮し た多目的最適化問題となる ${ }^{6-9)}$ 。とりわけ部材長は, 前述の複数の性 能に密接に関係する。

Basso et al. ${ }^{11)}$ は, データベースを用いて部材長を数種類に限定す る手法を提案した。藤井ら ${ }^{10)}$ は, 接合部のコストを考慮した最適化 手法を提案した。部材の種類を減らすことで, 接合部の取り合い種 類や, 網目形状をパターン化できる。例えば, 三角形グリッドで全 ての部材の長さが同じであれば, 部材角がすべて 60 度に近い值とな るため, 接合部種類が限定され, 網目形状も正三侜形で統一される ため仕上げパターンも均一になってコストの削減につながる。また, 極端に長い, あるいは短い部材の存在は, 個材座屈附力に影響する ほか, 部材長が不均一だと, 部材間の角度が小さくなり接合部の制 作が困難になる場合がある。さらに, 網目の形状も不均等となり, 意 匠的にも好ましくない。しかし, 既往の研究では, 部材長の完全な 一様化は達成できていない。

\footnotetext{
*1 金箱構造設計事務所 修士(工学) (広島大学 社会人博士課程)

*2 広島大学大学院工学研究院建築学専攻 教授 ·博士 (工学)
}

Kanebako Structural Eng.

(Graduate Student, Hiroshima Univ.)

Prof., Dept. of Architecture, Hiroshima Univ., Dr. Eng. 
本論文では, ラチスシェルに対して, 力学的性能と非力学的性能 を同時に考慮することを意図して, 剛性と部材長一様性を目的とし た形状最適化を行う。最適化には, 数理計画法を用いるため, 多く の部材で構成されるラチスシェルの全ての部材に長さの制約を与え ると, 収束性が極めて悪くなる。一方, 部材長の一様性の指標とし て部材長の偏差（分散に部材数を乗じた量）を採用すると，一様性 に関する制約条件は一つであり，かつ部材長の一様性を定量的に評 価できる。

また, 曲面の滑らかさを維持して自由な形状を表現するため, べ ジエ曲面を用いる。三角形グリッドのラチスシェルに対しては, 三 角形パッチベジエ曲面を用いる12)。最適化例として, 三角形ならび に四辺形グリッドで構成されるラチスシェルに対して，ひずみエネ ルギーと部材長の偏差を最小化する多目的最適化問題を, 制約法を 用いて解き,さまざまな設計変数を用いた場合の最適形状の特性を 比較する。

\section{2 剛性最大化と部材長一様化のための最適化問題}

$m$ 個の部材からなる $n$ 自由度のラチスシェルを考える。部材は節 点で剛接合されるものとし, 静的荷重に対する応答を, 梁要素を用 いて解析する。 $n$ 個の成分をもつ変位べクトルを $\boldsymbol{d}, n \times n$ の剛性行 列を $\boldsymbol{K}$ とする。節点位置を定める設計変数のベクトルを $\boldsymbol{x}$ とする と, $\boldsymbol{d}$ と $\boldsymbol{K}$ は $\boldsymbol{x}$ の関数であり, ひずみエネルギー $f(x)$ は次式で定 義できる。

$$
f(x)=\frac{1}{2} d(x)^{\top} \boldsymbol{K}(\boldsymbol{x}) \boldsymbol{d}(\boldsymbol{x})
$$

剛性の向上を目的とした古典的な構造最適化問題では, ひずみエネ ルギーを最小化する。しかし，それにともなって非常に長い部材や 短い部材が得られる可能性がある。そのため, 以下のように部材長 の一様化を考慮する。

部材 $k$ の長さを $l_{k}(\boldsymbol{x})$, それらの平均值を $l_{\mathrm{ave}}(\boldsymbol{x})$ とすると, 部材 長の偏差（分散に部材長を乗じた量） $g(\boldsymbol{x})$ は次式で定義できる。

$$
g(\boldsymbol{x})=\sum_{k=1}^{m}\left(l_{k}(\boldsymbol{x})-l_{\mathrm{ave}}(\boldsymbol{x})\right)^{2}
$$

ひずみエネルギー $f(\boldsymbol{x})$ と部材長の偏差 $g(\boldsymbol{x})$ の 2 つの目的関数を最 小化する多目的最適化問題を, 制約法13)を用いて解く。

まず, $g(\boldsymbol{x})$ に上限值 $\bar{g}$ を与え, $f(\boldsymbol{x})$ を目的関数として最小化す る。さらに, 最適化によってライズの大きい構造が得られるのを防 ぐため, 部材長の総和 $L(\boldsymbol{x})$ に上限值 $L_{0}$ を与えて, 次のような最適 化問題を考える。

$$
\begin{array}{ll}
\text { minimize } & f(\boldsymbol{x}) \\
\text { subject to } & \left\{\begin{array}{l}
L(\boldsymbol{x})-L_{0} \leq 0 \\
g(\boldsymbol{x}) \leq \bar{g}
\end{array}\right.
\end{array}
$$

以下の最適化例では， $L_{0}$ は初期形状での総部材長とする。

$\bar{g}$ を 0 とすると部材長は完全に一様化される。しかし， $\bar{g}$ が小さ い場合, 設計変数の種類と初期形状によっては, 制約条件を満たす 解が存在しない場合がある。その場合は, 目的関数と制約関数を入 れ替えた次の最適化問題を解く。

$$
\begin{array}{ll}
\text { minimize } & g(\boldsymbol{x}) \\
\text { subject to } & \left\{\begin{array}{l}
L(\boldsymbol{x})-L_{0} \leq 0 \\
f(\boldsymbol{x}) \leq \bar{f}
\end{array}\right.
\end{array}
$$

ひずみエネルギーの上限值 $\bar{f}$ に適切な值（例えば初期形状での值） を指定することにより, 一定の剛性を確保しつつ, 部材長を可能な 限り一様化することができる。

3 ラチスシェルモデルのパラメトリック曲面による定義 3.1 ラチスシェルモデル
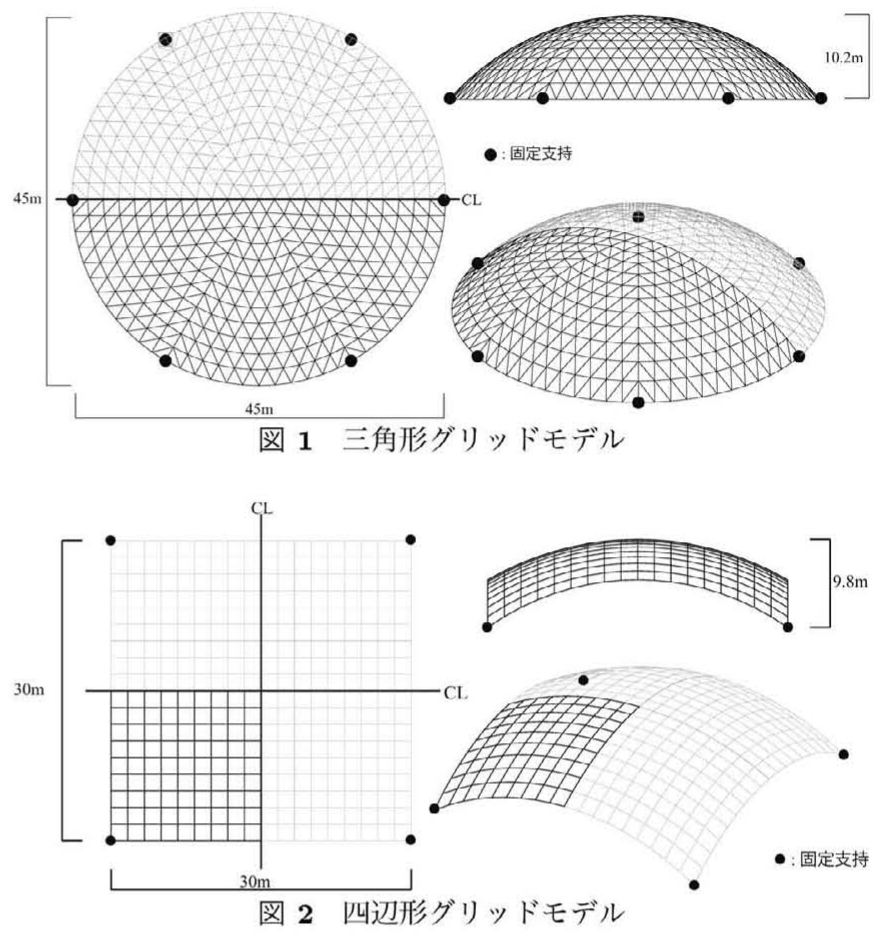

図 1 に示す, 三角形グリッドで構成されたスパン $45 \mathrm{~m}$ の円形平 面を有するシェル，ならびに図 2 に示す, 四辺形グリッドで構成さ れたスパン $30 \mathrm{~m}$ の正方形平面を有するシェル対して, 種々の形状最 適化を行う。いずれのモデルも，境界条件は図の○点を固定支持と する。

パラメトリック曲面によって曲面形状を表現することにより，少 ない変数で十分に複雑かつ滑らかな形状を定義できる。以下では, 三 角形と四辺形のグリッドを有するラチスシェルを, 三角形パッチベ ジエ曲面ならびにテンソル積ベジエ曲面により表現する14)。

3.2 三角形パッチベジエ曲面による三角形グリッドラチスシェルの 形状定義

曲面上の位置を定めるパラメータを $u, v \in[0,1](u+v \leq 1)$ とす ると, $u, v$ は面積座標ともいわれ, $(x, y, z)$ 空間内の曲面 $\boldsymbol{S}_{I}(u, v)=$ $(x(u, v), y(u, v), z(u, v))^{\top}$ を次のように表すことができる。

$$
\boldsymbol{S}_{I}(u, v)=\sum_{i=0}^{I} \sum_{j=0}^{I-i} \boldsymbol{q}_{i j} B_{I, i j}(u, v)
$$

ここで, $\boldsymbol{q}_{i j}=\left(q_{x, i j}, q_{y, i j}, q_{z, i j}\right)^{\top}$ は制御点座標, $B_{I, i j}(u, v)$ は次数 $I$ の 2 変数のバーンスタイン基底関数である。 $u=0, v=0$ あるい は $u+v=1$ の曲線の制御点の個数は $I+1$ であり, 制御点の総数は $(I+1)(I+2) / 2$ となる。

式 (5) の曲面を， $u, v$ 方向にそれぞれ $I^{\prime}$ 個に分割してラチス シェルのグリッドを構成する。したがって, ラチスシェルの節点数 は $\left(I^{\prime}+1\right)\left(I^{\prime}+2\right) / 2$ であり, 曲面上の節点位置は, 次のパラメー夕 
ベクトル $u, v$ で定義される。

$$
\boldsymbol{u}=\left[u_{0}, \cdots, u_{I^{\prime}}\right]^{\top}, \quad \boldsymbol{v}=\left[v_{0}, \cdots, v_{I^{\prime}}\right]^{\top}
$$

節点の $x, y, z$ 座標をそれぞれ並べたべクトルを $\boldsymbol{r}_{x}, \boldsymbol{r}_{y}, \boldsymbol{r}_{z}$ とす る。例えば， $\boldsymbol{r}_{x}$ は次のようになる。

$$
\begin{aligned}
\boldsymbol{r}_{x}= & {\left[x\left(u_{0}, v_{0}\right), \cdots, x\left(u_{I^{\prime}}, v_{0}\right), x\left(u_{0}, v_{1}\right), \cdots,\right.} \\
& \left.x\left(u_{I^{\prime}-1}, v_{1}\right), \cdots, x\left(u_{0}, v_{I^{\prime}}\right)\right]^{\top}
\end{aligned}
$$

制御点の $x, y, z$ 座標をそれぞれ並べたベクトルを $\boldsymbol{q}_{x}, \boldsymbol{q}_{y}, \boldsymbol{q}_{z}$ とす る。例えば， $\boldsymbol{q}_{x}$ は次のようになる。

$$
\boldsymbol{q}_{x}=\left[q_{x, 00}, \cdots, q_{x, I 0}, q_{x, 01}, \cdots, q_{x,(I-1) 1}, \cdots, q_{x, 0 I}\right]^{\top}
$$

曲面上の節点座標は制御点座標および曲面パラメータを用いて次 のように書ける。

$$
\begin{aligned}
x\left(u_{\alpha}, v_{\beta}\right) & =\sum_{i=0}^{I} \sum_{j=0}^{I-i} q_{x, i j} B_{I, i j}\left(u_{\alpha}, v_{\beta}\right) \\
y\left(u_{\alpha}, v_{\beta}\right) & =\sum_{i=0}^{I} \sum_{j=0}^{I-i} q_{y, i j} B_{I, i j}\left(u_{\alpha}, v_{\beta}\right) \\
z\left(u_{\alpha}, v_{\beta}\right) & =\sum_{i=0}^{I} \sum_{j=0}^{I-i} q_{z, i j} B_{I, i j}\left(u_{\alpha}, v_{\beta}\right) \\
& \left(\alpha, \beta=0, \cdots, I^{\prime}, \quad \alpha+\beta \leq=I^{\prime}\right)
\end{aligned}
$$

以下の最適化例では, 図 1 の解析モデルの $1 / 6$ の部分を, 4 次の 三角形パッチベジエ曲面を用いて図 3 のように表す $\left(I=4, I^{\prime}=12\right)$ 。 ここで, 太い実線は制御多角形, 黒丸は制御点であり, 図 3 の制御 点座標は, 曲面形状が球形に近くなるように決定した。

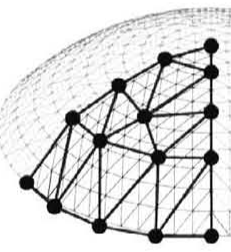

図 3 三角形グリッドシェルの三角形パッチベジエ曲面による離散化

3.3 テンソル積ベジエ曲面による四辺形グリッドラチスシェルの形 状定義

曲面上の位置を定めるパラメータを $s, t \in[0,1]$ とし, $(x, y, z)$ 空 間内の曲面 $\boldsymbol{S}_{I, J}(s, t)=(x(s, t), y(s, t), z(s, t))^{\top}$ を $s, t$ それぞれを 変数とするバーンスタイン基底関数の積として次のように表す。

$$
\boldsymbol{S}_{I, J}(s, t)=\sum_{i=0}^{I} \sum_{j=0}^{J} \boldsymbol{q}_{i j} B_{I, i}(s) B_{J, j}(t)
$$

ここで, $\boldsymbol{q}_{i j}=\left(q_{x, i j}, q_{y, i j}, q_{z, i j}\right)^{\top}$ は制御点座標, $B_{I, i}(s), B_{J, j}(t)$ は，パラメー夕 $s, t$ 方向のバーンスタイン基底関数である。 $I, J$ は $B_{I, i}(s), B_{J, j}(t)$ それぞれの次数であり, $s, t$ が一定の曲線上の制御点 の個数はそれぞれ $I+1, J+1$ であり, 制御点の総数は $(I+1)(J+1)$ となる。

式 (10) の曲面を， $s, t$ 方向にそれぞれ $I^{\prime}$ 個， $J^{\prime}$ 個に分割し，全 体として $\left(I^{\prime}+1\right)\left(J^{\prime}+1\right)$ 個の節点で四辺形グリッドのラチスシェル を構成する。曲面上の節点位置は, 次のパラメータベクトル $s, t$ で 定義される。

$$
\boldsymbol{s}=\left[s_{0}, \cdots, s_{I^{\prime}}\right]^{\top}, \quad \boldsymbol{t}=\left[t_{0}, \cdots, t_{J^{\prime}}\right]^{\top}
$$

節点の $x, y, z$ 座標をそれぞれ並べたべクトルを次のように定める。

$\boldsymbol{r}_{x}=\left[x\left(s_{0}, t_{0}\right), \cdots, x\left(s_{0}, t_{J^{\prime}}\right), \cdots, x\left(s_{I^{\prime}}, t_{0}\right), \cdots, x\left(s_{I^{\prime}}, t_{J^{\prime}}\right)\right]^{\top}$

$\boldsymbol{r}_{y}, \boldsymbol{r}_{z}$ も同様である。制御点座標ベクトルを次のように定める。

$$
\boldsymbol{q}_{x}=\left[q_{x, 00}, \cdots, q_{x, 0 J}, \cdots, q_{x, I 0}, \cdots, q_{x, I J}\right]^{\top}
$$

$\boldsymbol{q}_{y}, \boldsymbol{q}_{z}$ も同様である。

曲面上の節点座標は, 制御点座標および曲面パラメータを用いて 次のように書ける。

$$
\begin{aligned}
x\left(s_{k}, t_{l}\right) & =\sum_{i=0}^{I} \sum_{j=0}^{J} q_{x, i j} B_{I, i}\left(s_{k}\right) B_{J, j}\left(t_{l}\right) \\
y\left(s_{k}, t_{l}\right) & =\sum_{i=0}^{I} \sum_{j=0}^{J} q_{y, i j} B_{I, i}\left(s_{k}\right) B_{J, j}\left(t_{l}\right) \\
z\left(s_{k}, t_{l}\right) & =\sum_{i=0}^{I} \sum_{j=0}^{J} q_{z, i j} B_{I, i}\left(s_{k}\right) B_{J, j}\left(t_{l}\right) \\
& \left(k=0, \cdots, I^{\prime}, \quad l=0, \cdots, J^{\prime}\right)
\end{aligned}
$$

以下の最適化例では, 図 2 のモデルについて, 6 次のテンソル積 ベジエ曲面を用いて図 4 のように表す $\left(I=J=6, I^{\prime}=J^{\prime}=18\right)$ 。 ここで, 太い実線は制御多角形, 黒丸は制御点であり, 図 4 の制御 点座標は, 曲面形状が球形に近くなるように決定した。

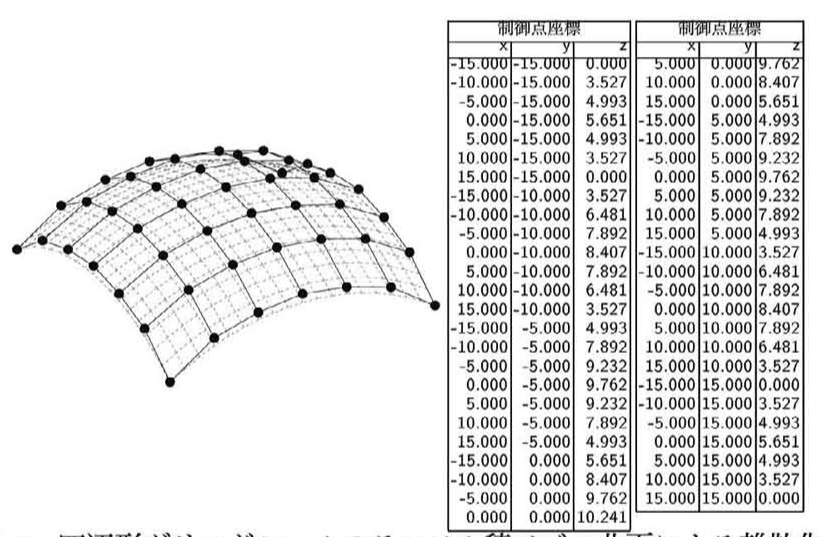

図 4 四辺形グリッドシェルのテンソル積ベジエ曲面による離散化

既往のラチスシェルの最適化に関する研究では, 各節点の $z$ 座標 $\boldsymbol{r}_{z}$ を設計変数とする場合が多い。また，変数を減らすためにパラメ トリック曲面を用いる場合でも， $s, \boldsymbol{t}$ や $\boldsymbol{u}, \boldsymbol{v}$ を固定值とし， $\boldsymbol{q}_{z}$ を設 計変数とすることで計算コストを低減する場合が多い。しかし, 部 材長を一様化するためには, 高い形状表現の自由度を必要とするた め, 設計変数は $\boldsymbol{q}_{z}$ のみでは不十分である。

本論では, 節点座標 $\boldsymbol{r}_{x}, \boldsymbol{r}_{y}, \boldsymbol{r}_{z}$ を設計変数とした場合, 制御点座 標 $\boldsymbol{q}_{x}, \boldsymbol{q}_{y}, \boldsymbol{q}_{z}$ を設計変数とした場合, さらに, 曲面上の節点位置を 定めるパラメータ $s, t$ あるいは $u, v$ を設計変数とした場合について, 最適形状の特性を考察する。

\section{4 三角形グリッドシェルの最適化例}

以下の最適化例では, 部材断面は外径 $165.2 \mathrm{~mm}$, 厚さ $4.5 \mathrm{~mm}$ の円形鋼管とする。ヤング係数を $210 \mathrm{GPa}$ ，単位体積当たり重量を $77.0 \mathrm{kN} / \mathrm{m}^{3}$ とし, 外力として自重を作用させる。最適化手法には逐 次二次計画法15)を用い, 設計変数に関する $f(\boldsymbol{x})$ 及び $g(\boldsymbol{x})$ の感度係 数は，差分法によって求める。図 3 のように制御点が与えられた図 1 
の形状を初期解とし, 対称性を考慮して弾性解析は半分の領域につ いて行う。

以下の最適化結果の眓において, $d_{\max }$ は最大鉛直方向変位, $l_{\max }$, $l_{\min }$ はそれぞれ最大, 最小部材長である。また, 総部材長の上限值 $L_{0}$ は初期形状での值とする。

\section{1 節点の $z$ 座標を設計変数とした場合}

まず，古典的な最適化問題として，パラメトリック曲面による形 状定義を用いず，節点の鉛直方向座標 $\boldsymbol{r}_{z}$ を設計変数としてひずみ工 ネルギーを最小化する。ライズが大きい最適形状が得られることを 防ぐため, 総部材長が図 1 の初期解での值 $L_{0}$ 以下になる制約を与 えると, 最適化問題は次のようになる。

$$
\begin{array}{ll}
\text { minimize } & f\left(\boldsymbol{r}_{\boldsymbol{z}}\right) \\
\text { subject to } & L\left(\boldsymbol{r}_{\boldsymbol{z}}\right)-L_{0} \leq 0
\end{array}
$$

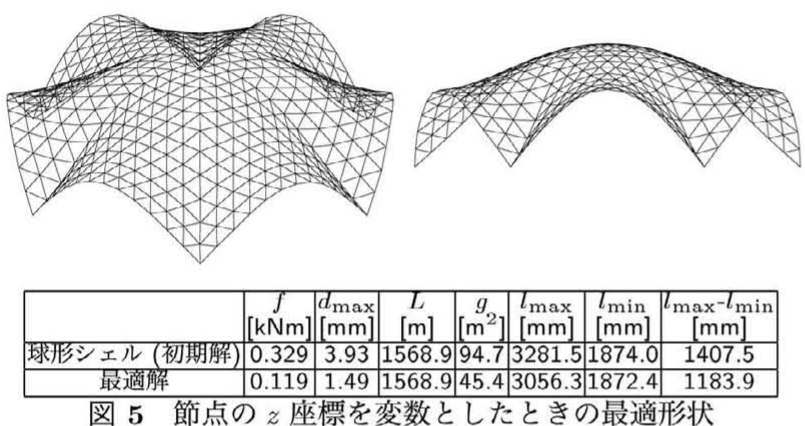

最適化結果を図 5 に示す。図 5 より, 最適化によって, 支点間の ライズがカテナリー状に上昇し, 高い剛性を持ったシェル形状が得 られたことが分かる。ただし, 部材長の一様化を考慮していないの で, $l_{\max }-l_{\min }$ は極めて大きい值となっている。

4.2 節点の $x y z$ 座標を変数とした場合

部材長を一様化することを目的とし, 節点の $x y z$ 座標を設計変数 として, 部材長の偏差に非常に小さい上限值 $\bar{g}=0.0001\left[\mathrm{~m}^{2}\right]$ を与え て最適化問題 (16) を解く。

$$
\begin{array}{ll}
\text { minimize } & f\left(\boldsymbol{r}_{\boldsymbol{x}}, \boldsymbol{r}_{\boldsymbol{y}}, \boldsymbol{r}_{\boldsymbol{z}}\right) \\
\text { subject to } & \left\{\begin{array}{l}
L\left(\boldsymbol{r}_{\boldsymbol{x}}, \boldsymbol{r}_{\boldsymbol{y}}, \boldsymbol{r}_{\boldsymbol{z}}\right)-L_{0} \leq 0 \\
g\left(\boldsymbol{r}_{\boldsymbol{x}}, \boldsymbol{r}_{\boldsymbol{y}}, \boldsymbol{r}_{\boldsymbol{z}}\right) \leq 0.0001
\end{array}\right.
\end{array}
$$

\begin{tabular}{|c|c|c|c|c|c|c|}
\hline & & & $\stackrel{g}{g}$ & $\begin{array}{l}l_{\max } \\
{[\mathrm{mm}]}\end{array}$ & {$\left[\begin{array}{l}l_{\min } \\
{[\mathrm{mm}]}\end{array}\right.$} & $\begin{array}{c}l_{\max }-l_{\min } \\
{[\mathrm{mm}]}\end{array}$ \\
\hline 最適解 0.126 & & 1568. & 90.000 & 12315.2 & 22312.1 & 3.1 \\
\hline
\end{tabular}
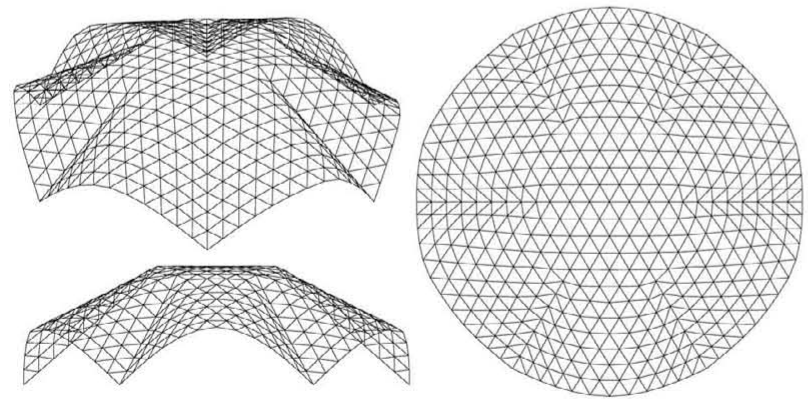

図 5 の解を初期形状として最適化を行った結果を図 6 に示す。最 適解において, 最大部材長と最小部材長の差は $3.1 \mathrm{~mm}$ であり, ひ
ずみエネルギーの值は初期解とほぼ変わらず，高い剛性を保ったま ま部材長を一様化することができた。ただし，節点座標を直接変数 としたため, 三角形グリッドは正三角形で構成され, 中央付近は平 面，周辺部は筒状曲面となり，全体として滑らかさに欠ける形状に なっている。

4.3 制御点の $z$ 座標を変数とした場合

曲面を三角形パッチベジエ曲面によりモデル化し, 制御点の $z$ 座 標を設計変数としてひずみエネルギーを最小化する。総部材長に関 する制約を与えると，最適化問題は次のようになる。

$$
\begin{array}{ll}
\text { minimize } & f\left(\boldsymbol{q}_{\boldsymbol{z}}\right) \\
\text { subject to } & L\left(\boldsymbol{q}_{\boldsymbol{z}}\right)-L_{0} \leq 0
\end{array}
$$

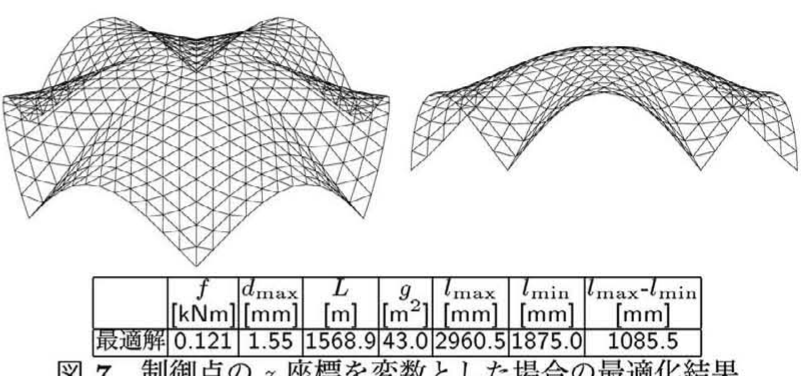

図 7 制御点の $z$ 座標を変数とした場合の最適化結果

最適化結果を図 7 に示す。図 7 より, 節点の $z$ 座標を設計変数と した場合の図 5 とほとんど同じ最適形状を得ることができた。した がって，ひずみエネルギーを最小化する場合には，4 次の三角形パッ チベジエ曲面によって, 十分な精度で最適曲面を表現できる。

4.4 制御点の $x y z$ 座標を変数とした場合

部材長を完全に一様化することを目的とし, 制御点の $x y z$ 座標を 設計変数として, 部材長の偏差に非常に小さい上限值 $\bar{g}=0.0001\left[\mathrm{~m}^{2}\right]$ を与えて最適化問題 (18) を解く。

$$
\begin{array}{ll}
\text { minimize } & f\left(\boldsymbol{q}_{\mathfrak{x}}, \boldsymbol{q}_{\boldsymbol{y}}, \boldsymbol{q}_{\boldsymbol{z}}\right) \\
\text { subject to } & \left\{\begin{array}{l}
L\left(\boldsymbol{q}_{\boldsymbol{x}}, \boldsymbol{q}_{\boldsymbol{y}}, \boldsymbol{q}_{\boldsymbol{z}}\right)-L_{0} \leq 0 \\
g\left(\boldsymbol{q}_{\boldsymbol{x}}, \boldsymbol{q}_{\boldsymbol{y}}, \boldsymbol{q}_{\boldsymbol{z}}\right) \leq 0.0001
\end{array}\right.
\end{array}
$$

図 7 の解を初期形状として最適化を行った結果を図 8 に示す。
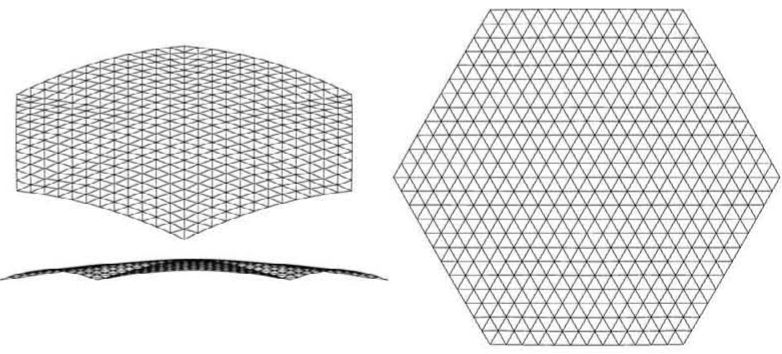

\begin{tabular}{|c|c|c|c|c|c|c|c|}
\hline & $\left.\begin{array}{c}f \\
{[\mathrm{kNm}]}\end{array}\right] \begin{array}{c}d_{\max } \\
{[\mathrm{mm}]}\end{array}$ & $\begin{array}{c}L \\
{[\mathrm{~m}]}\end{array}$ & $\begin{array}{c}g \\
{\left[\mathrm{~m}^{2}\right]}\end{array}$ & $\begin{array}{c}l_{\max } \\
{[\mathrm{mm}]}\end{array}$ & $\begin{array}{c}l_{\min } \\
{[\mathrm{mm}]}\end{array}$ & $\begin{array}{c}l_{\max }-l_{\min } \\
{[\mathrm{mm}]}\end{array}$ \\
\hline 最適解 & 1.075 & 14.92 & 1280.7 & 0.0001 & 1890.4 & 1887.8 & 2.6 \\
\hline
\end{tabular}

図 8 制御点の $x y z$ 座標を変数とした場合の最適化結果

パラメトリック曲面によって離散化したことによる実行可能領域 の縮小により, 部材長を一様化するのが困難となり, ほとんどライ ズを持たない形状となった。 
この結果に基づき，ひずみエネルギーと部材長の偏差を最小化す る問題を，以下のように，ひずみエネルギーに関する制約の下で部 材長の偏差を最小化する問題に変換する。

$$
\begin{array}{ll}
\text { minimize } & g\left(\boldsymbol{q}_{\boldsymbol{x}}, \boldsymbol{q}_{\boldsymbol{y}}, \boldsymbol{q}_{\boldsymbol{z}}\right) \\
\text { subject to } & \left\{\begin{array}{l}
L\left(\boldsymbol{q}_{\mathfrak{x}}, \boldsymbol{q}_{\boldsymbol{y}}, \boldsymbol{q}_{\boldsymbol{z}}\right)-L_{0} \leq 0 \\
f\left(\boldsymbol{q}_{\boldsymbol{x}}, \boldsymbol{q}_{\boldsymbol{y}}, \boldsymbol{q}_{\boldsymbol{z}}\right) \leq \bar{f}
\end{array}\right.
\end{array}
$$

多目的最適化問題に対する制約法に基づき， $\bar{f}$ の值を変化させなが ら問題 (19) の解を求めることにより, パレート解集合を得る。 $\bar{f}$ が $0.05,0.10,0.30[\mathrm{kNm}]$ のときのパレート解を図 9 に示す。また，ひ ずみエネルギーと部材長の偏差のトレードオフ関係を図 10 に示す。

ひずみエネルギーを小さくすると，部材長のばらつきは大きくな り, 節点が支点の近傍に集まり, 非現実的に短い部材が出現する。こ のことから，現実的な最適形状を得るためには，部材長の偏差を制 約する必要があることが分かる。
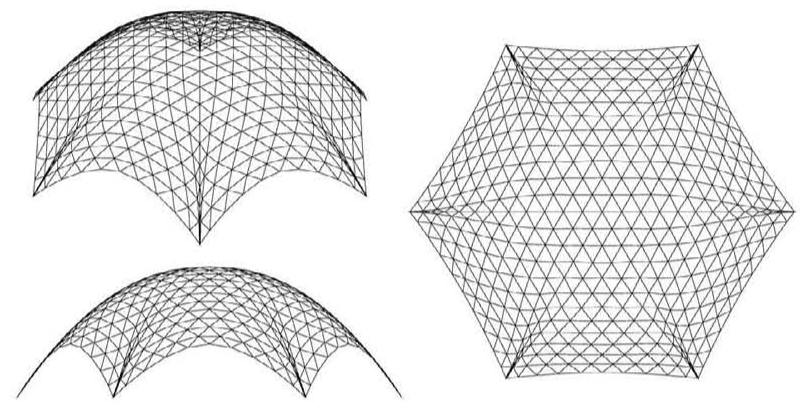

\begin{tabular}{|c|c|c|c|c|c|c|c|}
\hline & $\begin{array}{c}f \\
{[\mathrm{kNm}]}\end{array}$ & $\begin{array}{c}d_{\max } \\
{[\mathrm{mm}]}\end{array}$ & $\begin{array}{c}L \\
{[\mathrm{~m}]}\end{array}$ & $\begin{array}{c}g \\
{\left[\mathrm{~m}^{2}\right]}\end{array}$ & $\begin{array}{c}l_{\max } \\
{[\mathrm{mm}]}\end{array}$ & $\begin{array}{l}l_{\min } \\
{[\mathrm{mm}]}\end{array}$ & $\begin{array}{c}l_{\max }-l_{\min } \\
{[\mathrm{mm}]}\end{array}$ \\
\hline 最適解翟 0.050 & 1.28 & 1480.6 & 136.1 & 3004.0 & 228.5 & 2775.5 \\
\hline
\end{tabular}

(a) 最適解 $(\bar{f}=0.050[\mathrm{kNm}])$

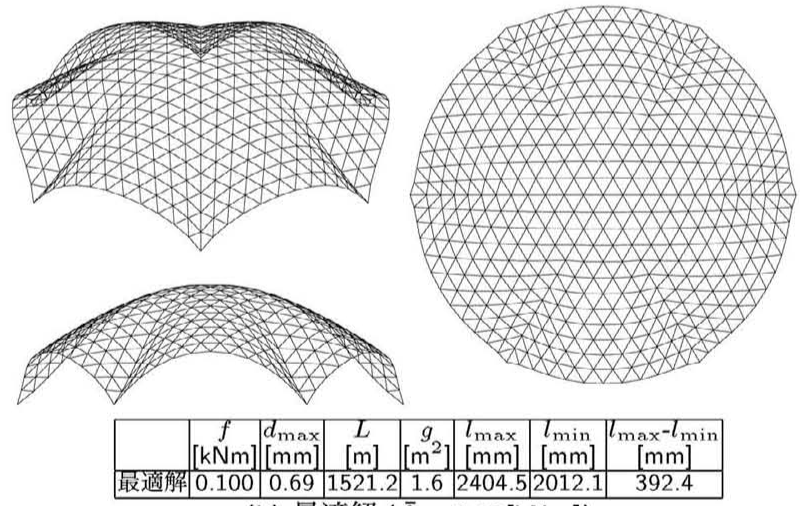

(b) 最適解 $(\bar{f}=0.10[\mathrm{kNm}])$
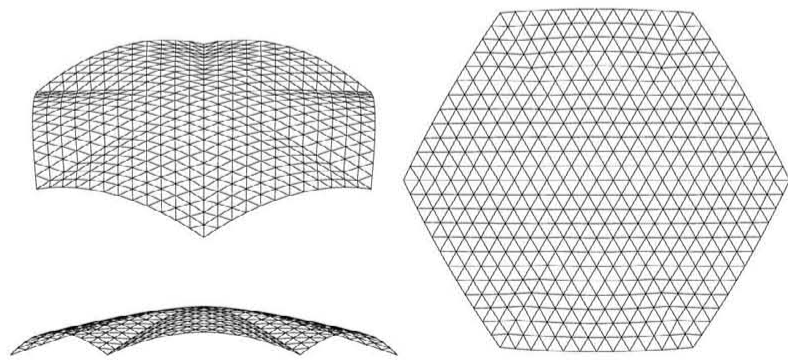

\begin{tabular}{|c|c|c|c|c|c|c|c|}
\hline & $\begin{array}{c}f \\
{[\mathrm{kNm}]}\end{array}$ & $\begin{array}{l}d_{\max } \\
{[\mathrm{mm}]}\end{array}$ & $\begin{array}{c}L \\
{[\mathrm{~m}]}\end{array}$ & $\begin{array}{c}g \\
{\left[\mathrm{~m}^{2}\right]}\end{array}$ & $\begin{array}{c}l_{\max } \\
{[\mathrm{mm}]}\end{array}$ & $\begin{array}{c}l_{\min } \\
{[\mathrm{mm}]}\end{array}$ & $\begin{array}{c}l_{\max }-l_{\min } \\
{[\mathrm{mm}]}\end{array}$ \\
\hline 最適解 & 0.300 & 4.17 & 1316.9 & 0.003 & 1948.0 & 1936.7 & 11.3 \\
\hline
\end{tabular}

(c) 最適解 $(\bar{f}=0.30[\mathrm{kNm}])$

図 9 最適化問題 (19) の最適解

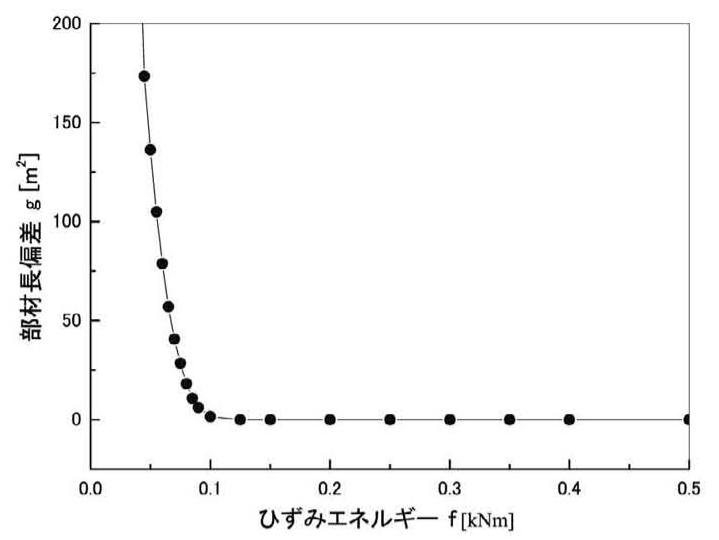

図 $10 \boldsymbol{q}_{x}, \boldsymbol{q}_{y}, \boldsymbol{q}_{z}$ を設計変数とした場合の $g$ と $f$ の関係

4.5 曲面上の節点位置を定めるパラメータを変数とした場合

制御点座標は動かさずに，曲面上の節点位置を定めるパラメータ $\boldsymbol{u}, \boldsymbol{v}$ を設計変数として形状を最適化する。これによって節点は常に 与えられたべジエ曲面上を動くため, 初期形状を維持したままひず みエネルギーの值や部材長の偏差を改善することができる。部材長 を完全に一様化するためには変数の自由度が十分でないので，まず， 図 1 の初期形状に対して, 次の最適化問題を解くことで, 部材長が 最も一様化された形状を求める。

$$
\begin{array}{ll}
\text { minimize } & g(\boldsymbol{u}, \boldsymbol{v}) \\
\text { subject to } & L(\boldsymbol{u}, \boldsymbol{v})-L_{0} \leq 0
\end{array}
$$
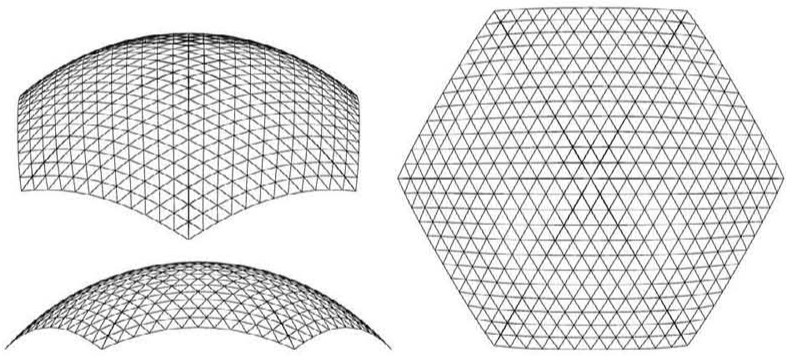

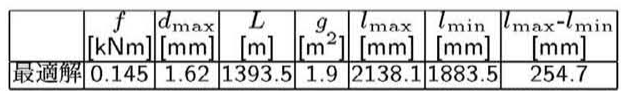

図 11 曲面上の節点位置を定めるパラメータを変数とした場合の最 適化結果

最適化結果を図 11 に示す。図 11 より, 形状を維持したまま, 部 材長の偏差を小さくできていることが分かる。ひずみエネルギーに ついては制約を与えていないが, 最適解での值は初期解での值のお よそ半分となっており, 剛性も向上している。

部材長の偏差を最小化したときのひずみエネルギーの值が 0.145 なので, 次の最適化問題

$$
\begin{array}{ll}
\text { minimize } & g(\boldsymbol{u}, \boldsymbol{v}) \\
\text { subject to } & \left\{\begin{array}{l}
L(\boldsymbol{u}, \boldsymbol{v})-L_{0} \leq 0 \\
f(\boldsymbol{u}, \boldsymbol{v}) \leq \bar{f}
\end{array}\right.
\end{array}
$$

について $\bar{f} \leq 0.145[\mathrm{kNm}]$ の範囲でひずみエネルギーの上限值 $\bar{f}$ 変化させて最適化を行った結果を図 12 に示す。また，ひずみエネル ギーと部材長の偏差の関係を図 13 に示す。 4.4 項の結果と同様に，ひ ずみエネルギーと部材長の偏差との間にはトレードオフ関係があり, 

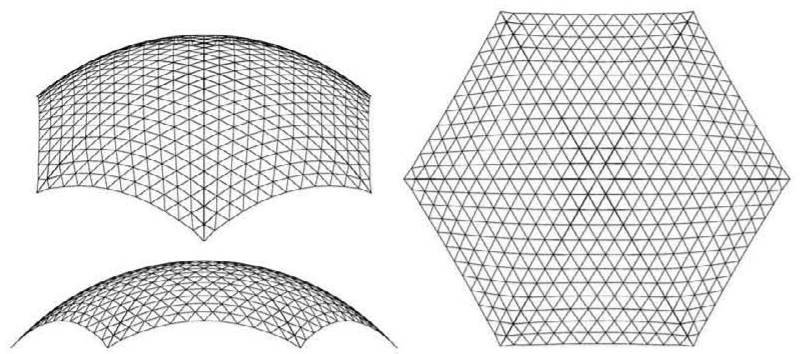
\begin{tabular}{|c|c|c|c|c|c|c|c|}
\hline & $\begin{array}{c}f \\
{[\mathrm{kNm}]}\end{array} d_{\max }$ & $\begin{array}{c}L \\
{[\mathrm{~mm}]}\end{array}$ & $\begin{array}{c}g \\
{\left[\mathrm{~m}^{2}\right]}\end{array}$ & $\begin{array}{l}l_{\max } \\
{[\mathrm{mm}]}\end{array}$ & $\begin{array}{l}l_{\min } \\
{[\mathrm{mm}]}\end{array}$ & $\begin{array}{c}l_{\max }-l_{\min } \\
{[\mathrm{mm}]}\end{array}$ \\
\hline 最適解 & 0.120 & 1.48 & 1354.7 & 7.9 & 2228.3 & 1396.4 & 832.0 \\
\hline
\end{tabular}

(a) 最適解 $(\bar{f}=0.12[\mathrm{kNm}])$
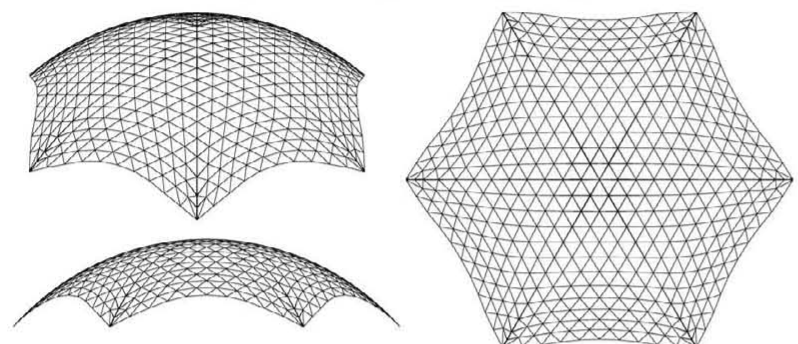

\begin{tabular}{c|c|c|c|c|c|c|c|}
\hline $\mathrm{kNm}]$ & $d_{\max }$ & $\begin{array}{c}L \\
{[\mathrm{~mm}]}\end{array}$ & $g^{2}$ & $l_{\max }$ & $l_{\min }$ & $l_{\max }-l_{\min }$ \\
{$\left[\mathrm{m}^{2}\right]$} & {$[\mathrm{mm}]$} & {$[\mathrm{mm}]$} & {$[\mathrm{mm}]$} \\
\hline
\end{tabular}

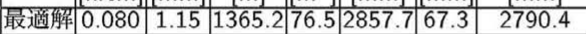

(b) 最適解 $(\bar{f}=0.08[\mathrm{kNm}])$

図 12 最適化問題 (21) の最適解

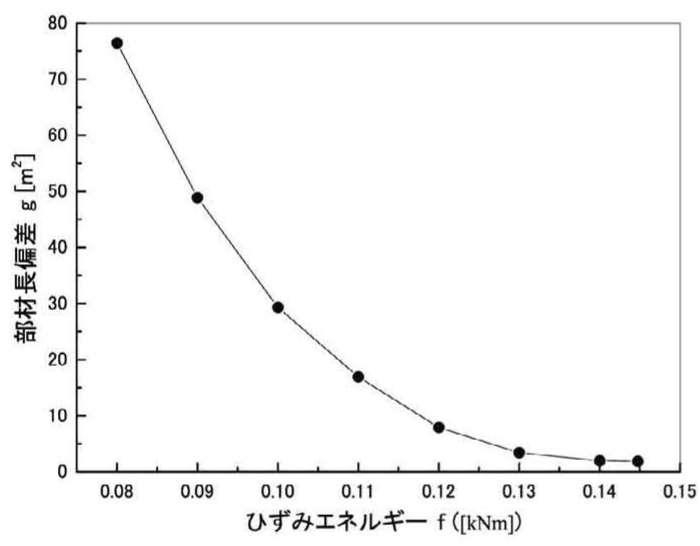

図 $13 u, v$ を設計変数とした場合の $g$ と $f$ の関係

部材長のばらつきを許容してひずみエネルギーを抑えるにしたがい, 節点が支点の近傍に集まり，極端に短い部材が現れる傾向にある。

\section{5 四辺形グリッドシェルの最適化例}

四辺形グリッドシェルを対象として最適形状を求める。部材の断 面，材料特性などは，三角形グリッドシェルと同じである。また，図 4 のように制御点が与えられた図 2 の解を初期形状とし, 対称性を 考慮して弾性解析は $1 / 4$ の領域のみ行う。

\section{1 節点の $z$ 座標を設計変数とした場合}

節点の鉛直方向座標 $\boldsymbol{r}_{z}$ を設計変数とし，曲面形状のパラメトリッ ク表現を用いずにひずみエネルギーを最小化する。総部材長に関す る制約を与えると, 最適化問題は次のようになる。

$$
\begin{array}{ll}
\text { minimize } & f\left(\boldsymbol{r}_{\boldsymbol{z}}\right) \\
\text { subject to } & L\left(\boldsymbol{r}_{\boldsymbol{z}}\right)-L_{0} \leq 0
\end{array}
$$

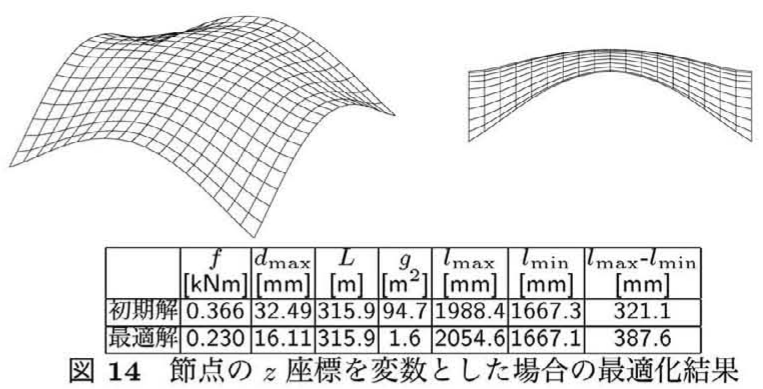

最適化結果を図 14 に示す。三角形グリッドシェルと同様に, 支点 間のライズがカテナリー状に上昇し，高い剛性を持ったシェル形状 が得られた。

\section{2 節点の $x y z$ 座標を変数とした場合}

部材長を完全に一様化することを目的とし, 制御点の $x y z$ 座標を 設計変数として, 部材長の偏差に非常に小さい上限値 $\bar{g}=0.0001\left[\mathrm{~m}^{2}\right]$ を与えて最適化問題 (23) を解く。

$$
\begin{array}{ll}
\text { minimize } & f\left(\boldsymbol{r}_{\boldsymbol{x}}, \boldsymbol{r}_{\boldsymbol{y}}, \boldsymbol{r}_{\boldsymbol{z}}\right) \\
\text { subject to } & \left\{\begin{array}{l}
L\left(\boldsymbol{r}_{\boldsymbol{x}}, \boldsymbol{r}_{\boldsymbol{y}}, \boldsymbol{r}_{\boldsymbol{z}}\right)-L_{0} \leq 0 \\
g\left(\boldsymbol{r}_{\boldsymbol{x}}, \boldsymbol{r}_{\boldsymbol{y}}, \boldsymbol{r}_{\boldsymbol{z}}\right) \leq 0.0001
\end{array}\right.
\end{array}
$$

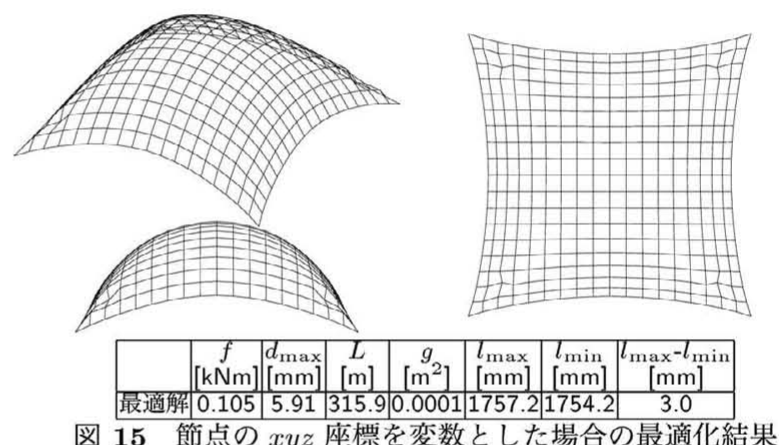

図 14 の解を初期形状として最適化した結果を図 15 に示す。最大 部材長と最小部材長の差は $3.0 \mathrm{~mm}$ であり, ひずみエネルギーの值 は初期解の $1 / 3$ と大きく向上しており, 剛性を高めながら部材長を 一様化することができた。ただし，節点座標を変数としたため，支 点近傍で滑らかさに欠ける形状となっている。

5.3 制御点の $z$ 座標を変数とした場合

曲面をテンソル積ベジエ曲面によりモデル化し, 制御点の $z$ 座標 を設計変数として以下の問題を解くことにより，ひずみエネルギー を最小化する。

$$
\begin{array}{ll}
\text { minimize } & f\left(\boldsymbol{q}_{\boldsymbol{z}}\right) \\
\text { subject to } & L\left(\boldsymbol{q}_{\boldsymbol{z}}\right)-L_{0} \leq 0
\end{array}
$$

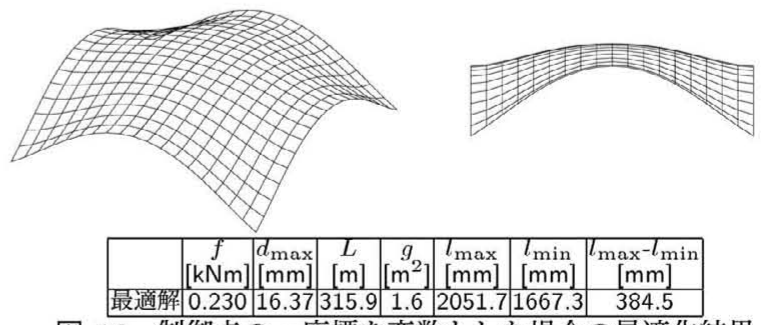

図 16 制御点の $z$ 座標を変数とした場合の最適化結果 
最適化結果を図 16 に示す。三角形グリッドの場合と同様に, 節点 の $z$ 座標を設計変数とした場合の図 14 の最適解とほぼ同様の最適形 状を得ることができた。

\section{4 制御点の $x y z$ 座標を変数とした場合}

部材長を完全に一様化することを目的とし，制御点の $x y z$ 座標を 設計変数として, 部材長の偏差に非常に小さい上限值 $\bar{g}=0.0001\left[\mathrm{~m}^{2}\right]$ を与えて最適化問題 $(25)$ を解く。

$$
\begin{array}{ll}
\text { minimize } & f\left(\boldsymbol{q}_{\boldsymbol{x}}, \boldsymbol{q}_{\boldsymbol{y}}, \boldsymbol{q}_{\boldsymbol{z}}\right) \\
\text { subject to } & \left\{\begin{array}{l}
L\left(\boldsymbol{q}_{\boldsymbol{x}}, \boldsymbol{q}_{\boldsymbol{y}}, \boldsymbol{q}_{\boldsymbol{z}}\right)-L_{0} \leq 0 \\
g\left(\boldsymbol{q}_{\boldsymbol{x}}, \boldsymbol{q}_{\boldsymbol{y}}, \boldsymbol{q}_{\boldsymbol{z}}\right) \leq 0.0001
\end{array}\right.
\end{array}
$$

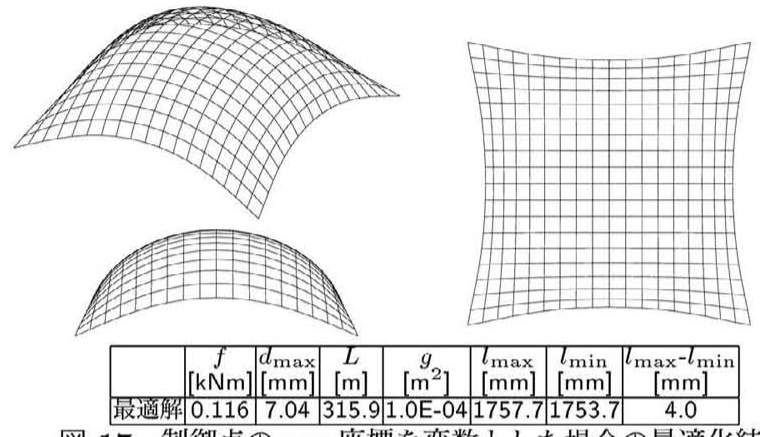

図 17 制御点の $x y z$ 座標を変数とした場合の最適化結果

図 16 の形状を初期形状として得られた最適形状を図 17 に示す。 最大部材長と最小部材長の差は $4 \mathrm{~mm}$ であり, 三角形グリッドの場 合と異なり，パラメトリック曲面によって離散化したことで実行可 能領域が縮小しても, 部材長をほぼ一様化することができた。その 理由としては，四辺形グリッドでは，部材数の節点数に対する比（部 材密度）が，三角形グリッドと比べて小さく，幾何学的拘束が小さい ことが考えられる。また，最適解でのひずみエネルギーの值は，節 点座標を設計変数とした場合とほぼ同じであり, 支点近傍でも滑ら かな形状が得られている。

5.5 曲面上の節点位置を定めるパラメータを変数とした場合

制御点座標は動かさずに，曲面上の節点位置を定めるパラメー夕 $\boldsymbol{s}, \boldsymbol{t}$ を設計変数として形状を最適化する。部材長を完全に一様化する ためには変数の自由度が十分でないので，まず，図 2 の初期形状に 対して, 次の最適化問題を解くことで, 部材長が最も一様化された 形状を求める。

$$
\begin{array}{ll}
\text { minimize } & g(\boldsymbol{s}, \boldsymbol{t}) \\
\text { subject to } & L(\boldsymbol{s}, \boldsymbol{t})-L_{0} \leq 0
\end{array}
$$

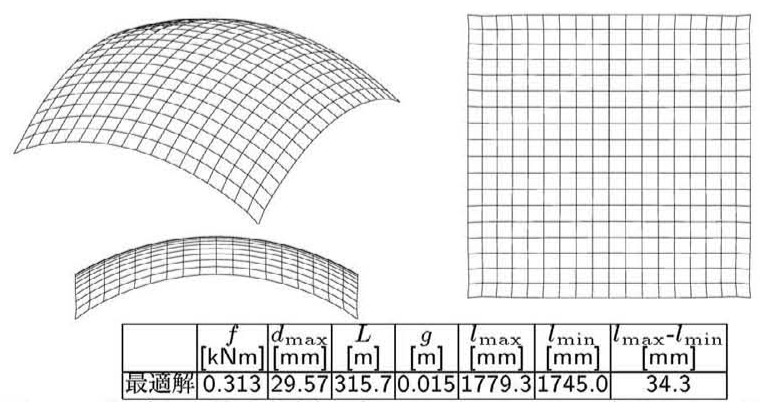

図 18 曲面上の節点位置を定めるパラメータを変数とした場合の最 適化結果
最適化結果を図 18 に示す。初期形状を維持したまま， $g$ の值は $94.7\left[\mathrm{~m}^{2}\right]$ から $0.015\left[\mathrm{~m}^{2}\right]$ に減少している。ひずみエネルギーの值は $0.313[\mathrm{kNm}]$ なので, 次の最適化問題

$$
\begin{array}{ll}
\text { minimize } & g(\boldsymbol{s}, \boldsymbol{t}) \\
\text { subject to } & \left\{\begin{array}{l}
L(\boldsymbol{s}, \boldsymbol{t})-L_{0} \leq 0 \\
f(\boldsymbol{s}, \boldsymbol{t}) \leq \bar{f}
\end{array}\right.
\end{array}
$$

について $\bar{f} \leq 0.313[\mathrm{kNm}]$ の範囲でひずみエネルギーの上限值 $\bar{f}$ を 変化させて最適化を行った結果を図 19 に示す。また，ひずみエネル ギーと部材長の偏差の関係を図 20 に示す。三角形グリッドの場合と 同様に, $f$ と $g$ との間にはトレードオフ関係があり, $g$ の值を緩和す るほど部材が支点に向かって流れるような配㯰へと変わり, 剛性の 向上と逆に部材長の一様性が失われていることが分かる。

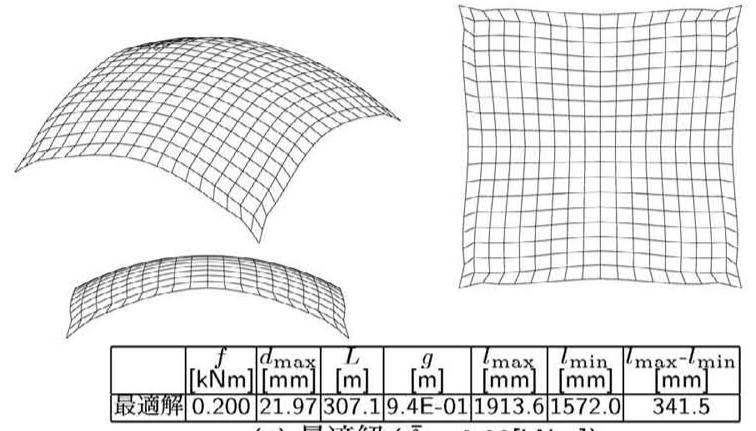

(a) 最適解 $(\bar{f}=0.20[\mathrm{kNm}])$

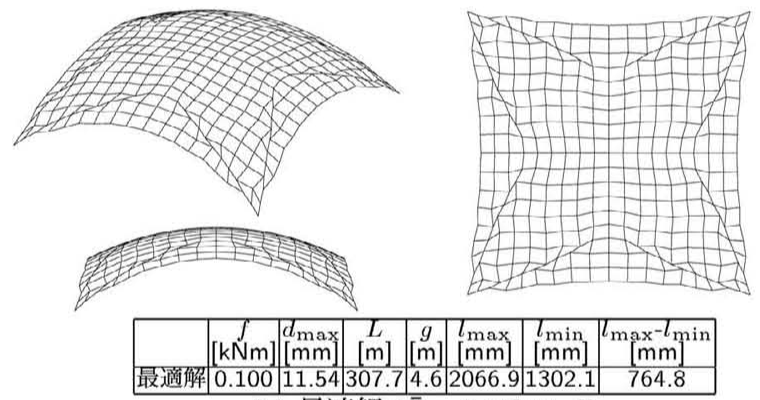

(b) 最適解 $(\bar{f}=0.10[\mathrm{kNm}])$

図 19 最適化問題 (27) の最適解

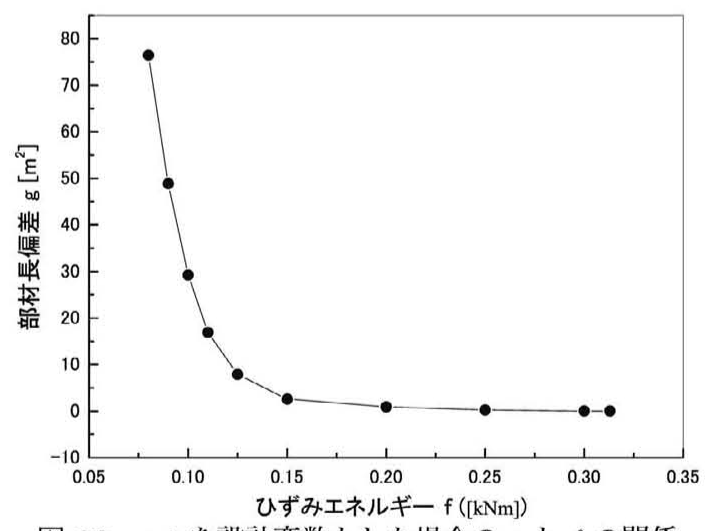

図 $20 s, t$ を設計変数とした場合の $g$ と $f$ の関係

\section{6 結論}

本論文では，三角形グリッドならびに四辺形グリッドで構成され たラチスシェルを対象として形状を最適化し, 解の特性を考察した。 
力学的な指標としてひずみエネルギー, 非力学的な指標として部材 長の偏差を採用し, さまざまな設計変数を用いて最適化し, 剛性と 部材長の一様さの間のトレードオフ関係を検討した。

本論文で得られた成果は以下の通りである。

1. ひずみエネルギーと部材長の偏差の最小化を目的とした多目的 最適化問題に対して, ひずみエネルギーを制約する問題と, 部材 長の偏差を制約する問題のいずれかを解くことにより, パレー 卜解集合を求めることができる。また, 部材長の偏差を微小な 值とすることで, 部材長の一様化されたラチスシェルを得るこ とができる。

2. 節点の $x y z$ 座標をすべて設計変数とした場合, 最適化のための コストは大きいものの, 三角形グリッド，四辺形グリッドとも に剛性が高く部材長が完全に一様な解を得ることができた。グ リッド形状の滑らかさを重視する場合には, 部材長の偏差を制 約することで, 極めて長い部材や短い部材の出現を回避できる。

3. 制御点の $x y z$ 座標を設計変数とした場合, 少ない解析コストで 滑らかな曲面形状を得ることができる。しかし，節点を直接設 計変数とした場合と比べて形状表現の自由度が制限されるため, 部材密度が大きく幾何学的制約の厳しい三角形グリッドで部材 長を一様化すると，ライズをほとんど持たない形状となる。

4. 曲面上の節点位置を定めるパラメータを設計変数とした場合, 指定された形状を表現するべジエ曲面上を節点が移動するので, 形状表現は限定的であるが, 曲面形状を維持したまま最適化す ることができる。したがって, 意匠設訃者のイメージする曲面 を初期形状として最適化を行うことにより, 意匠性を維持した まま各種性能を向上させることが可能となる。

表 1 設計変数と形状表現の関係

\begin{tabular}{|c|c|c|}
\hline 設䛨変数 & 形状の複雑さ & 形状の滑らかさ \\
\hline 節点 & (0) & $\Delta$ \\
\hline $\begin{array}{c}\text { 制御点 } \\
\text { パラメータ }\end{array}$ & $\triangle$ & (9) \\
\hline
\end{tabular}

節点座標を設計変数とする場合, 制御点座標を設計変数とする場 合, パラメー夕を設計変数とする場合について, 形状表現の特性は 表 1 のようにる。したがって, 最適化の目的によって, 以下のよ うな分類ができる。

1. ひずみエネルギーあるいは部材長の偏差などの目的関数を最小 化することを優先する場合は, 節点座標を設計変数とする。と くに, 部材密度の大きい三角形グリッドラチスシェルの部材長 を完全に一様化するためには, 節点座標を設計変数とするのが 有効である。しかし, 節点座標を変数とした場合には, 曲面や 部材配置の滑らかさが失われる可能性がある。

2. 曲面と部材配置の滑らかさを重視する場合は, 制御点座標を変 数とするのが望ましい。

3. 曲面形状が指定された場合は, 指定形状をべジエ曲面によって 表現し，その曲面上の節点位置を定めるパラメー夕を変数とす ることで, 剛性や部材長のばらつきを改善できる。

4. 曲面形状について, 局所的な制約を与える場合は，筆者らの提 案した代数不変量制約 ${ }^{16)}$ を導入して, 制御点座標の值を制御し た上でパラメータを修正することで, 設計者の形状のイメージ を保持したまま性能を向上させることも可能である。

\section{参考文献}

1) P. Pedersen: On the optimal layout of multi-purpose trusses, Comput. Struct., Vol. 2, pp. 695-712, 1972.

2) E. A. Sadek: Dynamic optimization of framed structures with variable layout, Int. J. Numer. Methods Eng., Vol. 23, pp. 1273-1294, 1986.

3) K. Svanberg: Optimization of geometry in truss design, Comput. Methods Appl. Mech. Engrg., Vol. 28, pp. 63-80, 1981.

4) M. P. Saka and and M. Ulker: Optimum design of geometrically nonlinear space trusses, Comput. Struct., Vol. 42(3), pp. 289-299, 1991.

5) 小河利行, 大崎 純, 立石理恵: 線形座屈荷重最大化と部材長一様化を目的 とした単居ラチスシェルの形状最適化. 日本建築学会構造系論文集, No.570, pp.129-136, 2003.8.

6) 大森博司, 山本憲司: 応力分布を目的関数とする空間構造の形状最適化に関する 研究 その 2 スペースフレームへの適用. 日本建築学会構造系論文集, No.503, pp.77-83, 1998.1 .

7) 山本憲司, 皆川洋一, 大森博司: 座屈荷重を目的関数とする空問構造の形状最適 化に関する研究. 日本建築学会構造系論文集, No.564, pp.95-102, 2003.2.

8) 山本憲司, 皆川洋一, 大森博司: 剛性行列のブロック対角化を利用した線形座 屈荷重を目的関数とする単層トラスドームの形状最適化. 日本建築学会構造系 論文集, No.578, pp.51-58, 2004.4.

9) 沖田裕介, 和田大典, 本間俊雄: 解の多様性を考虑した GA 系解法によるラチ スシェル構造の形態創生, コロキウム構造形態の解析と創生 2010 , 日本建築学 会, pp.121-126, 2010.

10）藤井英二，荒木慶一，上谷宏二：接合コストを考虑した自由曲面鋼構造の形状 · 断面最適化. 日本建築学会構造系論文集, No.670, pp.2123-2132, 2011.12.

11) P. Basso, A. E. del Grosso, A. Pugnale and M. Sassone: Computational Morphogenesis in Architecture: Cost Optimization of FreeForm Grid Shells, J. Int. Assoc. for Shell and Spatial Struct., Vol.50, No.3, pp. 143-150, 2009.

12) M.Ohsaki, T. Nakamura and M.Kohiyama: Shape optimization of a double-layer space truss described by a parametric surface. Int. J. Space Structures, Vol.12(2), pp.109-119, 1997.

13) M. Ohsaki, Optimization of Finite Dimensional Structures, CRC Press, 2010.

14) G. Farin: CAGD のための曲線・曲面理論, 共立出版, 1991.

15) P. Gill, W. Murray and M. Saunders: User's Guide for SNOPT Version 7 : Software for Large-Scale Nonlinear Programming, Stanford Business Software Inc., 2008.

16) 藤田慎之輔, 大崎 純: ひずみエネルギーとパラメトリック曲面の代数不変量を考 虑したシェルの形状最適化. 日本建築学会構造系論文集, No.639, pp.857-863, 2009.5 .

（2012年 8 月 9 日原稿受理，2012年11月21日採用決定） 